\title{
Prevention of stunting in school children through the utilization of local food in the form of tamban fish (Spratelloides gracilis) and spinach at Rugemuk Village Labu beach district
}

\author{
Ernawati Nasution $^{1 *}$, Etti Sudaryati ${ }^{1}$, Fitri Ardiani ${ }^{1}$ \\ ${ }^{1}$ Departement of Publick Healt, Faculty of Public Healt, Universitas Sumatra Utara \\ *Email: nasutionernawati38@yahoo.com
}

\begin{abstract}
Tamban fish and spinach are one type of food that is beneficial to health. Aside from being a staple food, tamban fish have good nutritional content such as protein, fat, calcium, phosphorus, iron, vitamin A, vitamin B1 and vitamin C. Meanwhile, spinach contains fiber and antioxidants that are high enough to meet the body's needs. However, processed food based on tamban fish and spinach leaves until now is still lacking due to lack of consuming tamban fish because it has a lot of thorns and consumes less spinach because it doesn't like eating vegetables. So in this service, another method is introduced for the utilization of these two foodstuffs by processing them into meatballs from tamban fish and spinach in fulfilling nutritional intake, especially in children in preventing stunting. The method used in this training is counseling and practice which includes providing material with lectures through face to face, dialogue and questions and answers and discussion. The training that has been carried out provides understanding and skills to the people of the Rugemuk Village in Pantai Labu Subdistrict, in the use of tamban fish and spinach that are processed into fish flour as ingredients for making meatballs which are functional food, participants' responses when providing training and material about the content nutrition in tamban and spinach leaves and their use in other forms is quite positive. The participants were very enthusiastic during the training as seen from the many participants who asked. And the practice of making meatballs from tamban fish flour and spinach leaves carried out also succeeded in increasing the knowledge and skills of the participants in regards to processing tamban fish and spinach leaves. It is hoped that the active role of the participants in disseminating information about the use of tamban fish and spinach leaves which can be processed into fish meal as ingredients in making meatballs to other communities in their surroundings.
\end{abstract}

Keyword: meatballs, tamban fish flour, spinach leaves

\begin{abstract}
Abstrak
Ikan tamban dan bayam merupakan salah satu jenis makanan yang bermanfaat bagi kesehatan. Selain sebagai pangan pokok, ikan tamban memiliki kandungan gizi yang baik seperti protein, lemak, kalsium, fosfor, zat besi, vitamin A, vitamin B1 dan vitamin C. Sementara itu, bayam mengandung serat dan antioksidan yang cukup tinggi untuk memenuhi kebutuhan tubuh. Namun olahan pangan berbasis ikan tamban dan daun bayam sampai saat ini masih sangat kurang disebabkan kurangnya mengonsumsi ikan tamban karena memiliki banyak duri dan kurang mengonsumsi bayam karena tidak suka makan sayur. Maka dalam pengabdian ini dikenalkan cara lain untuk pemanfaatan kedua bahan makanan ini dengan pengolahannya menjadi bakso dari tepung ikan tamban dan bayam dalam memenuhi asupan gizi terutama pada anak dalam pencegahan stunting. Metode yang digunakan dalam pelatihan ini adalah penyuluhan dan praktek yang meliputi pemberian materi dengan ceramah melalui tatap muka, dialog dan tanya jawab serta diskusi. Pelatihan yang telah dilakukan ini memberikan pemahaman dan keterampilan kepada masyarakat Desa Rugemuk di wilayah Kecamatan Pantai Labu, dalam pemanfaatan ikan tamban dan bayam yang diolah menjadi tepung ikan sebagai bahan untuk pembuatan bakso yang merupakan pangan fungsional, tanggapan peserta pada saat pemberian pelatihan dan materi tentang kandungan gizi pada ikan tamban dan daun bayam serta pemanfaatannya dalam bentuk lain cukup positif. Peserta sangat antusias selama mengikuti pelatihan dilihat dari banyaknya peserta yang bertanya. Dan praktek pembuatan bakso dari tepung ikan tamban dan daun bayam yang dilakukan juga berhasil menambah pengetahuan dan keterampilan peserta salam pengolahan ikan tamban dan daun bayam. Diharapkan peran aktif para peserta untuk menyebarluaskan informasi tentang pemanfaatan ikan tamban dan daun bayam yang dapat
\end{abstract}


diolah menjadi tepung ikan sebagai bahan dalam pembuatan bakso kepada masyarakat lain dilingkungan sekitar mereka.

Kata Kunci: bakso, tepung ikan tamban, daun bayam

\section{PENDAHULUAN}

Kualitas bangsa di masa depan ditentukan oleh kualitas anak-anak saat ini. Keadaan gizi kurang dapat ditemukan pada setiap kelompok masyarakat. Anak sekolah yang kekurangan gizi disebabkan oleh kekurangan gizi pada masa balita dan kurangnya konsumsi gizi yang seimbang dalam makanannya sehari-hari sehingga tidak adanya pencapaian pertumbuhan yang sempurna pada masa berikutnya. Anak-anak yang mengalami hambatan dalam pertumbuhan disebabkan kurangnya asupan makanan yang memadai dan penyakit infeksi yang berulang, dan meningkatnya kebutuhan metabolik serta mengurangi nafsu makan, sehingga meningkatnya kekurangan gizi pada anak. Keadaan ini semakin mempersulit untuk mengatasi gangguan pertumbuhan yang akhirnya berpeluang terjadinya stunted.

Stunting merupakan kegagalan untuk mencapai pertumbuhan optimal yang disebabkan oleh keadaan gizi kurang yang berlangsung dalam waktu yang lama. Stunting pada anak, selain disebabkan oleh defisiensi zat gizi makro, juga berhubungan dengan defisiensi seng (Zn). Seng (Zn) adalah mineral esensial yang berperan dalam sintesis, sekresi, dan kontrol hormon pertumbuhan (Growth Hormon). Rendahnya sintesis hormon pertumbuhan dapat menghambat pertumbuhan linier dan diduga menyebabkan kondisi stunting pada masa balita (Hidayati, 2011).

Indonesia mempunyai masalah gizi yang cukup berat yang ditandai dengan banyaknya kasus gizi kurang pada anak balita, usia masuk sekolah baik pada laki-laki dan perempuan. Masalah gizi pada anak usia sekolah dapat menyebabkan rendahnya kualiatas tingkat pendidikan, tingginya angka absensi dan tingginya angka putus sekolah (WKPG, 1998 dalam Sulastri, 2012). Saat ini penderita stunting tidak hanya terjadi pada balita, tetapi juga pada anak usia sekolah. Prevalensi nasional untuk kategori stunting $(\mathrm{TB} / \mathrm{U})$ pada anak usia sekolah dasar yaitu 5-12 tahun sebesar $30,7 \%$ dengan rincian, 12,3\% kategori sangat pendek dan 18,4\% kategori pendek (KEMENKES, 2013). Anak usia sekolah tergolong kelompok rentan gizi karena membutuhkan zat gizi dalam jumlah besar untuk menyokong pertumbuhan mereka. Hasil Riset kesehatan Dasar menunjukkan ada penurunan angka stunting dari 37,2 persen pada Riskesdas tahun 2013 menjadi 30,8 persen pada Riskesdas tahun 2018. Persentase ini termasuk tinggi, karena mengacu dari data WHO yang prevalensinya harus kurang dari 20 persen.

Prevalensi stunting di Sumatera Utara sebesar 43,2\% dengan kategori sangat pendek sebesar 20,6\% dan pendek sebesar 22,6\% (Depkes, 2010). Masalah kesehatan masyarakat dianggap berat bila prevalensi sangat pendek sebesar $30-39 \%$ dan serius bila prevalensi pendek $>40 \%$ (WHO, 2010).

Anak yang mengalami stunting dapat diperbaiki pertumbuhannya dengan cara mengejar perbaikan gizi pada anak tersebut. Anak-anak yang sudah terlanjur mengalami Stunting harus dilakukan perbaikan gizi secepatnya. Agar pertumbuhanya dapat dikejar. Istilah ini disebut Catch Up Growth. Perbaikan gizi ini dapat dilakukan dengan pemberian gizi yang seimbang tersebut harus memenuhi 50-60\% karbohidrat, 40\% lemak bagi anak di bawah usia 2 tahun dan maksimal $30 \%$ bagi anak di atas usia 2 tahun. Selain karbohidrat dan lemak, protein juga harus dipenuhi sebesar $10-15 \%$.

Desa Rugemuk merupakan salah satu desa di Kecamatan Pantai Labu, Kabupaten Deli Serdang dengan jumlah penduduk 2.795 jiwa. Jumlah anak usia 5-14 Stahun sebanyak 631 anak. Kabupaten Deli Serdang menyumbang angka stunting sebesar 18,7 \%. Hal tersebut menandakan bahwa daerah tersebut memiliki masalah stunting yang cukup tinggi.

Kecamatan Pantai Labu merupakan salah satu daerah pesisir yang sebagian besar penduudknya sebagai nelayan. Ikan selalu tersedia di daerah tersebut. Salah satu hasil tangkapan mereka yang selalu ada adalah ikan tamban. Ikan Tamban (Spratelloides gracilis) adalah salah satu 
bahan makanan yang biasa dikonsumsi oleh masyarakat Indonesia khususnya masyarakat Desa Rugemuk Kecamatan Pantai Labu. Kandungan gizi ikan tamban tiap 100 gram yaitu 20 gr protein, $3 \mathrm{gr}$ lemak, $20 \mathrm{mg}$ kalsium, $100 \mathrm{mg}$ fosfor dan $1 \mathrm{mg}$ zat besi. Ikan tamban juga memiliki kandungan EPA $(21,77 \%)$ dan DHA $(11,59 \%)$ cukup tinggi. EPA dan DHA adalah penyusun Omega 3. Ikan tamban sering dimanfaatkan sebagai ikan sarden, bahan tepung ikan atau bahan pakan ternak, kelebihan nilai EPA dan DHA menjadikan ikan tamban memiliki potensi besar sebagai obat dan produk kesehatan. Ikan ini banyak diperoleh di Desa Rugemuk Kecamatan Pantai Labu tetapi pengolahannya masih terbatas hanya diolah dengan di goreng. Sehingga sering tidak termanfaatkan secara maksimal.

Bayam juga merupakan salah satu sayuran yang mudah diperoleh oleh masyarakat Desa Rugemuk dan sering dikonsumsi. Bayam (Amaranthus spp, L) merupakan sayuran sumber zat gizi, yang banyak mengandung vitamin $\mathrm{A}$, vitamin $\mathrm{C}$ dan kalsium. Selain itu bayam juga mengandung karotenoid dan flavonoid yang merupakan zat aktif dengan khasiat antioksidan. Jenis karotenoid utama dalam bayam adalah beta karoten sedangkan zat aktif lainnya adalah klorofil. Jenis flavonoid yang terkandung di dalam bayam adalah kuersetin yang merupakan antioksidan kuat yang mampu menangkap radikal bebas dan menghambat oksidasi kolesterol LDL. Ada dua jenis bayam yaitu bayam hijau dan bayam merah. Keduanya kaya vitamin C, tetapi bayam hijau lebih kaya vitamin A sedangkan bayam merah lebih banyak mengandung zat besi (Suwita, 2011).

Salah satu upaya yang dilakukan agar ikan tamban yang banyak didapat di Desa Rugemuk Kecamatan Pantai Labu termanfaatkan secara maksimal adalah dengan diversifikasi pangan. Diversifikasi yang dilakukan adalah dengan mengenalkan olahan ikan tersebut menjadi bakso. Bakso umumnya digemari oleh semua kalangan baik orangtua, remaja dan terutama pada anakanak sekolah. Pengembangan bakso dalam pengabdian ini dilakukan dengan membuat bakso dari Ikan Tamban dengan penambahan bayam. Bakso yang dihasilkan dalam pengabdian ini dapat menjadi salah satu alternatif cara mengonsumsi bakso terutama pada anak-anak yang tidak suka mengonsumsi ikan akan mau jadi mengonsumsinya karena sudah dijadikan bakso.

\section{METODE PELAKSANAAN}

Permasalahan mitra di Desa Rugemuk Kecamatan Pantai Labu adalah masih kurang termanfaatkannya ikan tamban yang banyak terdapat dari hasil tangkapan dan kurangnya mengonsumsi bayam yang baik oleh masyarakat khususnya pada anak usia sekolah dasar sehingga diduga merupakan penyebab masih tingginya masalah stunting pada anak di Desa Rugemuk Kecamatan Pantai Labu.

Metode yang dilakukan dalam pengbdian ini adalah pelatihan dan praktek dalam pembuatan bakso. Kegiatan yang dilakukan dalam pelatihan ini adalah sebagai berikut :

1. Pemberian pemahaman tentang keunggulan ikan tamban dan bayam dari aspek gizi, alternatif cara pengolahan dan perannya dalam pemenuhan asupan protein.

2. Pemberian pemahaman proses pembuatan tepung ikan tamban kemudian diolah menjadi bakso dengan penambahan daun bayam.

3. Praktek dan latihan pembuatan bakso dari tepung ikan tamban dan bayam.

Berikut langkah-langkah dalam pembuatan bakso dari tepung ikan tamban dan bayam. Pembuatan bakso diawali dengan pembuatan tepung ikan tamban dan pemilihan bayam. Berikut proses pembuatan tepung ikan tamban :

1. Pilihlah ikan tamban yang masih segar.

2. Pisahkan ikan tamban dari daging dan tulangnya kemudian lakukan pencucian hingga bersih dengan air yang mengalir dan tiriskan.

3. Letakkan ikan yang sudah dicuci bersih kedalam loyang kemudian masukkan ke dalam oven dengan suhu 1050C selama 10-12 jam untuk menghilangkan kadar air dan mengeringkan ikan.

4. Keluarkan ikan yang sudah kering dari dalam oven kemudian haluskan ikan dengan menggunakan blender. 
5. Kemudian saring dengan menggunakan ayakan dengan mesh 80 .

6. Lakukan beberapa kali pengayakan sehingga diperoleh hasil tepung ikan tamban yang halus.

Berikut proses pengolahan bayam :

1. Pilihlah daun bayam yang segar.

2. Lakukan pencucian dan tiriskan daun bayam.

3. Setelah tiris, potong daun bayam menjadi potongan-potongan kecil.

Adapun alat dan bahan proses pembuatan bakso:

a. Bahan

1. Tepung ikan tamban $3 \mathrm{sdm}$

2. Tepung sagu $6 \mathrm{sdm}$

3. Bayam $10 \mathrm{gr}$

4. Daun sop secukupnya

5. Telur 2 butir (putih saja)

6. Bawang putih 9 siung

7. Bawang merah 3 siung

8. Merica bubuk secukupnya

9. Garam $1 \mathrm{sdt}$

10.Gula secukupnya

11.Air es secukupnya

b. Alat
1. Blender
2. Sendok
3. Baskom
4. Panci

Pembuatan bakso dilakukan seperti proses pembuatan bakso pada umumnya. Berikut tahapan dalam pembuatan bakso ikan tamban yaitu :

1. Siapkan bahan yang diperlukan seperti tepung ikan tamban, daun bayam, tepung sagu, bawang putih, bawang merah, gula pasir, garam, telur, merica bubuk, daun sop dan air es.

2. Masukkan dahulu bahan-bahan seperti bawang putih dan bawang merah kedalam blender hingga halus.

3. Tuangkan bawang putih dan bawang merah yang diblender tadi kedalam baskom kemudian masukkan bahan yang lain seperti tepung ikan tamban, tepung sagu, garam, gula pasir, merica bubuk dan putih telur lalu aduk rata.

4. Setelah tercampur rata kemudian masukkan irisan daun bayam, daun sop dan sedikit air es kedalam adonan lalu aduk rata sampai adonan bisa dibentuk menjadi bulatan.

5. Selanjutnya bentuk adonan menjadi bulatan-bulatan dengan cara letakkan adonan bakso dalam genggaman, kemudian remas adonan sehingga adonan akan keluar melalui antara jari jempol dan telunjuk membentuk satu bulatan.

6. Ambil bulatan bakso dengan menggunakan sendok dan masukkan bulatan bakso kedalam panci berisi air panas yang mendidih.

7. Rebus bulatan bakso dengan api sedang sampai mengambang, menunjukkan bakso sudah matang.

8. Bakso yang telah matang kemudian diangkat dan ditiriskan sampai dingin.

9. Bakso siap disajikan. 


\section{HASIL DAN PEMBAHASAN}

Pengabdian kepada masyarakat ini telah dilaksanakan pada masyarakat Desa Rugemuk di Aula Kantor Kepala Desa Rugemuk Kecamatan Pantai Labu yang merupakan wilayah Kerja Kecamatan Pantai Labu Kabupaten Deli Serdang pada hari Kamis tanggal 25 Juli 2019. Kegiatan ini dihadiri oleh masyarakat Desa Rugemuk sebanyak 55 orang. Masyarakat yang hadir sangat antusias dengan kegaitan ini.

Sebelum melaksanakan pengabdian, tim pengabdian menghubungi kepala desa untuk mengadakan kegiatan pengabdian dengan tema pemanfaatan pangan lokal berupa ikan tamban dan bayam dalam pencegahan stunting. Kegiatan ini dimulai dengan perkenalan pada masyarakat yang hadir pada acara ini kemudian kata sambutan oleh kepala desa rugemuk untuk kelangsungan acara tersebut.

Selanjutnya diberikan ceramah tentang ikan tamban dan bayam yang meliputi kandungan gizi dan pemanfaatan serta cara pengolahannya. Materi disampaikan dengan metode ceramah dan diskusi, peserta diberi kebebasan untuk bertanya dan berbagi pengalaman yang berkaitan dengan materi yang disampaikan. Selanjutnya diberi penjelasan cara pembuatan tepung ikan tamban mulai dari proses pemilihan, pengeringan dengan oven, dihaluskan dengan blender dan pengayakan sehingga dihasilkan tepung ikan tamban. Kemudian dilanjutkan dengan praktek pembuatan bakso tepung ikan tamban dan daun bayam.

Selama ini masyarakat mengetahui bahwa ikan tamban banyak memiliki tulang atau duri sehingga mereka jarang memberikan anak atau mengonsusmsi ikan tersebut padahal tanpa disadari bahwa ikan tamban banyak mengandung protein bahkan dalam pencegahan stunting pada anak mereka. Demikian juga dengan bayam yang memiliki banyak vitamin sehingga dapat dijadikan pendamping adonan dalam pembuatan bakso ikan tamban untuk meminimalisir anak yang tidak suka makan sayur. Pelatihan pembuatan tepung ikan tamban dan praktek pembuatan bakso dilakukan pada hari yang sama.

Hasil yang sudah dicapai dalam pengabdian ini adalah memperkenalkan teknologi sederhana dalam pembuatan tepung ikan tamban dan bayam yang kemudian tepung tersebut dapat diolah sebagai bahan pangan bergizi. Proses pengolahan tepung ikan tamban ini juga dapat meningkatkan daya simpan yang lama sehingga dapat dimanfaatkan dalam jangka yang panjang. Selesai pelaksanaan pengabdian di lapangan, selanjutnya adalah menyiapkan dokumentasi berupa youtube proses pembuatan tepung ikan tamban dan pengolahan bayam serta cara pembuatan baksonya.

Diakhir pelatihan ini juga fasilitator menyampaikan kepada peserta bahwa apa yang sudah didapat dan dilakukan para peserta dalam kegiatan ini untuk menyampaikan informasi yang mereka dapat kepada teman atau keluarga peserta. Sehingga informasi ini dapat diperoleh oleh semua masyarakat tidak hanya pada lingkungan dimana pelatihan ini dialkukan. Kegiatan ini diharapkan tidak hanya sekedar pelatihan saja tetapi juga dilanjutkan dengan bentuk penerapan dalam konsumsi makanan sehari-hari, sehingga dapat meningkatkan ketahanan pangan rumah tangga yang nantinya dapat meningkatkan ketahanan pangan rumah tangga level kecamatan maupun kabupaten.

\section{KESIMPULAN}

Kesimpulan dari kegiatan pengabdian ini adalah bahwa masyarakat Desa Rugemuk yang merupakan wilayah kerja Kecamatan Pantai Labu dapat memahami pemanfaatan ikan tamban dan bayam sebagai bahan makanan yang juga dapat diolah menjadi bakso yang memiliki kandungan gizi yang baik untuk pencegahan stunting pada anak. Bakso yang dihasilkan ini juga dapat meningkatkan ketahanan pangan keluarga dengan memanfaatkan bahan pangan lokal yang dapat diperoleh dengan mudah di daerah lingkungan setempat. 


\section{UCAPAN TERIMAKASIH}

Penulis mengucapkan terima kasih kepada Lembaga Pengabdian Kepada Masyarakat Universitas Sumatera Utara yang telah memberikan biaya Program Pengabdian Kepada Masyarakat, Skema Profesor Mengabdi, melalui dana NON PNBP Universitas Sumatera Utara

\section{DAFTAR PUSTAKA (REFERENCES)}

Depkes RI. 2010. Profil Kesehatan Indonesia 2010. Jakarta : Departemen Kesehatan Republik Indonesia.

Hidayati, L., Hadi, H. \& Kumara, A. 2010. "Kekurangan Energi dan Zat Gizi Merupakan Faktor Risiko Kejadian Stunted pada Anak Usia 1-3 Tahun yang Tinggal di Wilayah Kumuh Perkotaan Surakarta". Jurnal Kesehatan 3.

Kementrian Kesehatan RI. (2013). Laporan Hasil Riset Kesehatan Dasar (Riskesdas) Tahun 2013. Jakarta: Badan Penelitian dan Pengembangan Kesehatan.

Kementrian Kesehatan RI. (2018). Laporan Hasil Riset Kesehatan Dasar (Riskesdas) Tahun 2018. Jakarta: Badan Penelitian dan Pengembangan Kesehatan.

Sulastri, D. 2012. Faktor Determinan Kejadian Stunting pada anak Usia Sekolah di Kecamatan Lubuk Kilangan Kota Padang. Majalah Kedokteran Andalas No. 1. Vol.36. Hal : 41-50. Diakses 05 Desember 2014 dari http://mka.fk.unand.ac.id/images/articles/No_1_2012/hal_41-50_isi.pdf

Suwita, K. 2011. Pemanfaatan Bayam Merah (Blitum Rubrum) untuk Meningkatkan Kadar Zat Besi Dan Serat Pada Mie Kering. Jurusan Gizi Politeknik Kesehatan Kemenkes Malang 